\title{
Kur’an Tefsiri Bağlamında Yorumun Mahiyeti
}

\author{
Araştırma makalesi / Research article
}

\section{Şerket KOTAN*}

\section{Character of Interpretation in the Context of Quran Tafsir}

Citation/(C: Kotan, Şevket, (2020). Character of Interpretation in the Context of Quran Tafsir, Milel ve Nihal, 17 (1), 7-24.

Abstract: This article examines some of the foundations on which existential hermeneutics is based in comparison with the classical Quran tafsir models and focuses on new possibilities for the Quran tafsir. These foundations are related to interpreter as the subject of tafsir, text as the object of tafsir, and character of the interpretation as a consequence of this undertaking and inquiry itself. On the other hand, the discipline of classical Quran tafsir, despite focusing on the text historically, linguistically, and aesthetically, does not examine enough the character of human as the interpreting subject. This can be thought of as the weak side of the classical tafsir despite its historical, linguistic, and aesthetic successes. Because on the one side of the event of interpretation is the interpreter. The event of interpretation comes about as the outcome of the interpreter's effort in understanding the text. In this regard, hermeneutics is an approach that puts forward the interpreter by examining the character of the interpreter rather than of the text's and it strongly emphasizes the existential relationship between the interpretation and the interpreter.

Keywords: Tafsir, Interpretation, Hermeneutics, Disclosure of Existence, Subject-Object, Understanding, Historicity.

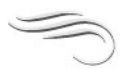

* Doç. Dr., İstanbul Üniversitesi, İlahiyat Fakültesi, Tefsir Anabilim Dalı [sevketkotan@yahoo.com] ORCID: 0000-0002-6491-7235. 
Atıf/C: Kotan, Şevket, (2020). Kur'an Tefsiri Bağlamında Yorumun Mahiyeti, Milel ve Nihal, 17 (1), 7-24.

Öz: Bu makale, klasik Kur'an tefsiri modellerine karşılık varoluşsal hermenötiğin üzerine oturduğu bazı temelleri inceleyerek, Kur'an tefsiri için yeni/farklı imkanlar üzerinde durmaktadır. Bu temeller, tefsirin öznesi olarak müfessirin, başka bir ifadeyle yorumcunun, nesnesi olarak ta metnin ve yorumcuyla metnin diyaloğunda ortaya çıkan yorum hadisesinin mahiyeti ile doğrudan ilişkilidir. Buna karşılık klasik tefsir disiplininin, tarihsel, dilsel ve sanatsal açıdan metnin üzerinde derinlemesine yoğunlaşmış olmasına rağmen anlayan/yorumlayan özne olarak insanın mahiyetine dair kayda değer bir soruşturma yapmadığı gözlenmektedir. Bu durum tarihsel, dilsel ve sanatsal açılardan elde ettiği başarısına rağmen klasik tefsir faaliyetinin zayıf tarafı olarak düşünülebilir. Çünkü yorum hadisesinin bir tarafında yorumcu vardır. Yorum hadisesi ise, yorumcunun metni anlama konusundaki çabasının bir hasılası olarak ortaya çıkmaktadır. Bu bakımdan hermenötik, metinden daha çok yorumcunun mahiyetini soruşturarak onu öne çıkaran bir yaklaşımdır ve yorum ile yorumcu arasındaki varoluşsal ilişkiyi güçlü şekilde vurgulamaktadır.

Anahtar Kelimeler: Tefsir, Yorum, Hermenötik, Varlığın İfşası, Özne-Nesne, Anlama, Tarihsellik.

\section{Giriş}

Tefsir metodolojisi mahiyetindeki usûl kitapları, anahatlarıyla iki bölümden meydana gelmektedirler. Bunlardan ilki, Kur'an tarihine ilişkindir. Bu bölümde Kur'an'ın nüzulünden başlayarak vahiy, vahyin yazıya geçirilmesi ve daha sonra cem edilerek çoğaltılması gibi konular işlenmektedir. Bununla okuyucu Kur'an tarihi hakkında bilgi sahibi olmaktadır. İkinci bölüm ise Kur'an'ın diline dairdir. Tefsir ve te'vil için mukaddime mesabesindeki bu bölümde Kur'an'ın dilsel özellikleri ve Kur'an'da yer alan edebî sanatlar işlenmektedir. Burada Kur'an dilinin gramatik yapısından edebi sanatlara kadar birçok konu, Kur'an'ın anlaşılmasında dikkat edilmesi gereken hususlar olarak geçer. Böylece müfessir ya da yorumcuya, Kur'an hakkındaki tarihsel bilgi yanında dil alimlerinin tartışmalarıyla açıklığa kavuşmuş bulunan dilsel sorunların rafine halleri sunulmaktadir.

Literatürde tefsir usulü olarak isimlenmiş olan fakat gerçekte metodolojik sistematik bakımından eksik bir muhtevaya sahip olan bu mukaddimlerin odaklandığı ana konu metindir. Tefsir usulü kitaplarında tefsir ya da yorum için sadece metin ve metne dair sorunlar üzerinde durulurken metni anlayan ve yorumlayan müfessir/yorumcunun metni anlama hususundaki tarihsel, varoluşsal ve 
yorumcu kaynaklı diğer sorunları üzerinde durulmamıştır. Halbuki yorum sadece metne ilişkin bir hadise olmaktan daha çok yorumcuya ilişkin bir hadisedir. Nitekim batıda 18. yüzyılın sonlarından başlayarak 20. yüzyılda büyük filozoflarla belli bir olgunluğa ulaşan anlama/yorumlamaya dair tartışmaların odak noktasında yorumun öznesi olarak insanın yer alması, Hıristiyan batı yorum geleneğinde de bulunan bu boşluğun keşfedilmesinin bir hasılasıdır. Tarihsel gelişmeler batı düşünce dünyasını bu eşiğe getirmişti.

Genel anlamda felsefi hermenötik açısından yorumun mahiyeti konusu, önümüze üç alt başlık çıkarıyor. Bunlar, 1- Yorumcu, 2-Metin, 3- Yorum. Yorumun mahiyetine ilişkin doğru bir bakış açısına sahip olma girişimi, yorumcu olarak insanın ve yorumun nesnesi olarak ta metnin mahiyeti hakkında varoluşsal temelde bir bakış açsına sahip olmayı zorunlu kılmaktadır. Zira yorum, yorumcu ve yorumun konusu olan metin birbirleriyle doğrudan ilişkilidirler. Bu nedenle yorumcu kavramı ile metin kavramı, yorumun mahiyeti konusu için mukaddime mesabesindedirler.

\section{A. Yorumcu}

Biraz önce değinildiği gibi, Aydınlanmanın süper özne mertebesine çıkardığı insan, çok geçmeden 18. yüzyılın ikinci yarısından itibaren eleştiri konusu olmuş, 20. yüzyıla gelindiğinde ise, varoluşsallık ve tarihsellik tartışmalarıyla yerini "tarihsel özne olarak insan"a bırakmıştır. Tarihsel özne olarak insan, bu felsefelerdeki insan tasarımından farklı şekilde, özne olduğu kadar aynı zamanda nesnedir. Çünkü bu yeni insan tasarımında dünyadan bağımsız şekilde var olabilen muhayyel bir insan tasavvuru yerine, ancak dünyada var olabilen ve ancak bu zorunlu ikamet ortamındaki koşullar içerisinde varlığını gerçekleştirebilen tarihsel insan tasavvuru vardır. Yeni tasavvura göre tarihsel bir mahiyet olan insan, ancak kendi tarihselliğinin koşulları içerisinde var olabilmektedir. Bu açıdan bakıldığında, zorunlu ikamet koşulları içerisinde bir varlık durumundaki insanın mahiyetinin temel kodlarına bakmak önemli hale gelmektedir. Bu kodlardan konumuz açısından en temel olanları aşağıdaki şekilde sıralanabilir.

\section{Dasein/Dünya-da Varlık}

Heidegger'in Dasein analizi, insanın mahiyetine dair insan düşüncesinin yeni bir evreye girmesine yol açmıştır. $O$, dünyada bir varlık olarak insanı Dasein olarak tanımlamış, Dasein analizine dayanan bu 
hermenötik anlayışına da Dasein hermenötiği ismini vermiş̧ir. Heidegger'in Being and Time (Varlik ve Zaman) isimli temel eserinde hermenötik ve ilgili konular hakkında derinleştirdiği düşünce, hem özelde hermenötik kelimesinin anlam alanı, hem de genelde bu konunun yer tuttuğu alanın tanımlanması ve geliştirilmesinde bir dönüm noktası olmuştur. Heidegger hermenötiği, insan varlı̆̆ının fenomenolojik açıdan mahiyeti ve bu mahiyetin açılanmasına odaklanan bir anlama ontolojisidir. Denilebilir ki Varlık ve Zaman baştan sona kadar "dünya-içinde-varolmaya fırlatılmış olan Dasein'in" 1 geniş boyutlu analizinden ibarettir. Burada Dasein, tarihsellik, yani zamansallık, mekansallık ve dilsellik bakımından incelenir. Heidegger'in Dasein analizinde anlama ve yorumlama da Palmer'ın ifadesiyle insan varlığının temel varoluşsal halleridir. ${ }^{2}$ Dasein, ontolojik olarak geleceğe dönük bir yapıya sahiptir. Bu nedenle o kendisini daima geleceğe doğru aşmaya çalışarak varlığını deneyimler. $D a-$ sein'in dünya ortamında tarihsel anlamasının yapısı, onun ontolojik arkabahçesinin bütünüyle birlikte ortaya çıkar. ${ }^{3}$

Dasein, "dünyada varlık" olarak tanımlanırken dünya ile kastedilen, çevre, nesnel yaklaşım ve bilimsel gözlemle algıladığımız evren değildir. Burada dünya kelimesiyle ifade edilmek istenen şey, tüm varlıklardan oluşan bütün değil, belki de bizim "onun dünyası", "bizim dünyamız" derken kastettiğimiz manaya daha yakın olan bir şeydir. Başka bir ifadeyle o, insanoğlunun kendisini görünürlülük ile çevrelenmiş ve içine gömülü olarak gördüğü bir totalitedir. Bu bakımdan dünyayı benlikten ayrı bir varlık olarak değil, onunla beraber bir bütün olarak görmek gerekir. Böyle görmeyince ortaya bir özne-nesne düalizmi çıkar ve insan, varlık alanını bu düalizm dolayımında algılamaya başlar. Bu da kendisiyle bir bütün olduğu dünya ve dünyada varlıklar arasında ötekileştirici bir mesafenin oluşmasına, dolayısıyla da dünya ile yabancılaşmasına neden olur. Halbuki dünya, benliğin nesnel anlamdaki dünyadan ayrılmasından daha önce de vardır, zira o, tüm nesnelliklerden ve hayallerden daha öncedir. Böyle olunca aslında o öznellikten de öncedir. Dünya, içerisindeki varlıkların sayılmaya çalışılması ile anlatılmış

1 Martin Heidegger, Varlık ve Zaman, çev. Kaan H. Ökten (İstanbul: Agora Kitaplığı, 2008), 176.

2 Richarde E. Palmer, Hermenötik, çev. İbrahim Görener (İstanbul: Anka Yayınları, 2002), 73.

3 Hans-Georg Gadamer, Hakikat ve Yöntem, çev. Hüsamettin Arslan, İsmail Yavuzcan (İstanbul: Paradigma Yayınları, 2008(, 1: 362. 
olamaz. Zira bu durumda dünyanın kendisine temas edilmemiş olur. Çünkü biraz önce temas edildiği gibi dünya, herhangi bir varlığı/varolanı bilme eyleminden önce, varsayılan olarak algılanması gereken bir şeydir. Dünyadaki her bir varlık, daima, söz konusu $b u$ dünya bağlamında-bir varlık olarak kavranır. Fiziksel dünyayı oluşturan varlıklar, bizzat bu dünyanın kendisi değil dünyada olan varlıklardır. Dolayısıyla gerçekte, sadece insanın dünyası vardır. ${ }^{4}$

Dünyanın kuşatıcılığı ve aynı zamanda yakınlığı, onun daima dikkatten kaçmasına neden olmaktadır. Halbuki insan her şeyi ancak onun içinden görebilmekte iken, hiç bir şeyi onsuz olarak saf kendi görünümünde görememektedir. Daima dikkatten kaçan, ama kaçınılmaz olarak var sayılmak durumunda olan bu kuşatıcı dünya, daimi saydam yapisiyla onu bir nesne olarak kavrama gayretlerine kapalı olarak vardır. Dünya, kendisinde ortaya çıkan varlıklar yanında hissedilen, ama yine sadece dünya içerisinde gerçekleşen bir şeydir. Dolayısıyla dünya ve anlama, Dasein'in varlığının ontolojik oluşumunda ayrılmaz cüzler olarak yer alırlar. ${ }^{5}$

\section{Tarihsel Varlık}

Dasein olarak insan, aynı zamanda ve her şeyden önce varolan anlamında tarihsel bir varlıktır. Hem varoluşsal olarak tarihsel bir varolan hem de tarih içerisinde eyleyen bir varolan olarak tarihsel bir varolandır. Bu bakımdan tarihin tarih yapan aktörleri insanlardır. Zira tarih, insan eylemleri ile varlık bulur. Dasein (dünyada-varlık) tanımıyla insan, bu dünya ortamında tarihselliğini deneyimlerken tarih oyununun baş aktörü olarak gerçek bir tarih senaryosu yazar. O tarih senaryosunu yazarken, ontolojik yapısına bağlı olarak geçmiş tarihsel birikimin meydana getirdiği bir tarihsellikte, bu tarihselliğin ona kazandırdığı arkaplan belirleyicidir. İnsanın tarihselliği, onun total kimliğinin tarihselliği, total kimliğinin en önemli yanını teşkil eden aklının tarihselliği anlamına gelir. Bu bakımdan aklı yanında, aklına yön veren duyguları, yani varlığının total kimliğini ifade eden bütün yönleri ile insan, tarihsel bir mahiyettir. ${ }^{6}$ Şayet bu bakış açısı varoluşsal bir temele dayanıyorsa, o halde aydınlanmacırasyonalist felsefelerin ana tasarımlarında yer alan salt akıl temelsiz hale gelir.

\footnotetext{
$4 \quad$ Heidegger, Varlik ve Zaman, 65-105.

Palmer, Hermenötik, 178-179.

Bk. Doğan, Özlem, Tarih Felsefesi (İstanbul: Ara Yayınları, 1992).
} 
Bu nedenle tarih, Dasein'in dünyasının varoluşsal ruhudur. İnsanı şekillendiren ana kucağı da bu ruhtur. Daha önceki bir çalışmamızda, insanın ve aklının tarihselliği konusunda batıdaki tartışmalar ve karşıt görüşler üzerinde detaylı bir şekilde durmuştuk. Tarihsellik ve hermenötiğin tarihi içerisinde süregelen tartışmalar ve bu tartışmalarla filizlenen düşüncenin rafinasyonu sonrasında artık metin, tarih ve insan, voruluşsal bir ilişkiler ağı içerisinde ele alınmaktadır. ${ }^{7}$

\section{Dil Varlı̆̆}

Gadamer, "Dili olanın dünyası da vardır", der. Çünkü insan varoluşsal olarak dünyayı dil ile tecrübe etmektedir. Dil, varlıkların s1nırsızlığı ile dolaysız bir ilişkiye sahiptir. İnsanoğlu tecrübesini kelimelere yerleştirerek, yani dile dökerek tecrübeyi yaşayan bir forma sokar. Dile sahip olmak, hayvanların içerisinde bulundukları habitatlarıyla sınırlı kalma modundan çok farklı bir varoluş moduna sahip olmayı içerir. Mesela insanlar yabancı bir dili öğrendiklerinde, kara hayvanı haline gelen bir su hayvanı gibi dünya ilişkilerini değiştiremezler, aksine, insanlar dünya ile mevcut ilişkilerini korurken, bu ilişkiyi yabancı dillerin dünyasıyla genişleterek zenginleştirirler. ${ }^{8}$

Her ne kadar pek çok kelime anlamı şekillendirmekte veya formüle etmekteyse de anlam, dünyada ilişkiler bütünü içerisine yerleşik olarak zaten dilden daha önceden vardır. Kelimeler, kendi sistemleri haricinde dünyadaki ilişkiler bütününde var olan ve buradaki ilişkiler bütünü içerisine yerleştirilmiş olan bir şeylerdir. Bu bakımdan anlamlılık ta, insanoğlunun nesneye kazandırdığı bir şey değil, bir nesnenin, dil ve kelimelerle ontolojik açıdan ifade edilmesinin mümkün kılınmasıyla insanlığa verilen şeydir. Diğer taraftan şeyler, öncelikle kelimeler ve dil içerisinde varlığa gelmiştir ve böylelikle var olabilmektedirler. Palmer'a göre Heidegger'in, meşhur "dil, varlığın meskenidir" sözü de böyle yorumlanmalıdır. ${ }^{9}$

Heidegger'e göre dilin varoluşsal-ontolojik temelini ise söz oluşturur. Varoluşsal olarak söz, bulunuş ve anlamayla eşit derecede aslidir. Söz anlaşılabirliğin dile gelişidir. Dolayısıyla açıklama

7 Bk. Şevket Kotan, Kur'an ve Tarihselcilik (İstanbul: Beyan Yayınları, 2001), 78-143.

8 Gadamer, Hakikat ve Yöntem, I: 276.

9 Palmer, Hermenötik, 181-182. 
ve ifade etmenin temelini oluşturmaktadır. Nitekim anlam da açıklama (tefsir) ve hatta daha asli olması bakımından söz etme sırasında dile getirilebilendir. Eğer söz, açımlanmışlığın asli varoluşu ise ve bu da dünya-içinde-varolmayla kuruluyorsa o zaman söz de asli olarak özgün dünyasal bir varlık mahiyetine sahiptir. Dünyaiçinde- varolmanın dünyadaki bulunuşsal anlaşılabilirliği kendini sözle dile getirir. Sözün açıkça dile getirilmişliğine dil denmektedir. Dünyada varolan sözcükler bütünü, bir dünya-içinde-varolan olarak sözcüklere ayrışmış halde karşımızda hazır halde bulunur. Zira söz, varoluşsal olarak dilin ta kendisidir. Sözlü konuşmaya, her biri birer imkân olarak duymak ve sükut da dahildir. ${ }^{10}$

Dasein kendini sözle dile getirir. Söz etme, daima bir şeyler hakkında söz etmedir. Her sözün arkasında bizatihi hakkında söz edilen vardır. Dilek, temenni, soru sorma ve hasbihal etmelerde bizatihi dile getirilenin kendisi vardır. Sözün kendini haberleşme-anlaşma konusu yapması da bunlar sayesinde olur. ${ }^{11}$

Hermenötik çalışmalarında dil meselesine büyük bir önem atfeden Gadamer ise, dil, dilin içinde meydana geldiği dünya ve onu yapan insan arasındaki varoluşsal ilişkiyi şöyle ifade etmektedir:

Dilin, içinde dile geldiği dünyadan ayrı hiçbir bağımsız hayatı olamaz. Yalnızca dünya dile girdiği ölçüde dünya olmakla kalmaz; aynı zamanda dil de dünyanın onda sunulmasındaki hakiki varlığına kavuşur. Bu yüzden, dilin kaynağı itibarı ile insani olması aynı zamanda insanın dünyaiçinde oluşunun/dünya-içindeki-varlığının (In-der-WeltSein) aslında linguistik olması manasına gelir. ${ }^{12}$

Gadamer'in bu bütünsel/tarihsel/varoluşsal bakış açısı, dünyanın ve dilin mahiyetine yönelik temel bir saptama olmanın yanında, insanın linguistik varoluşsal karakterine de esaslı bir vurgudur.

Öte taraftan geçmiş tarihin ve bunun gerçekleşme şekli olarak dönemsel tarihselliklerin dünyaya bıraktığı anlam dünyası da dilde mündemiçtir. Bu nedenle dil tarihselliktir. Çünkü dil hem tarihin en önemli taşıyıcısı hem de tarihselliğe anlam veren, tarihselliği mümkün kılan şeydir. Dünyaya atılmış olarak orada bir dil dünyasına

\footnotetext{
Heidegger, Varlık ve Zaman, 169-170.

Heidegger, Varlik ve Zaman, 171.

Gadamer, Hakikat ve Yöntem, 2: 253.
} 
gözlerini açan insan, zorunlu olarak varlığı dil ile görmekte, hatta dil vasıtasıyla düşünmektedir.

Buna karşılık olarak dil, tarihselliğin tezahür biçimidir ve bu karakteri itibariyle kendisi de tarihseldir. Çünkü dil, tarihselliğin kendisi ve tarihin kurucu unsuru olduğu gibi aynı zamanda tarihsel süreç içerisinde tarihsel insan tarafından dönüştürülen, şekillendirilen şeydir.

\section{Fani Varlık}

Ölüme, hitama doğru bir varlık olarak var edilen insan, varlığın anlamını ölümle, sonlulukla, havfla birlikte idrak etmektedir. Faniliğini idrak eden insan, kendi varlık imkanlarını sahici bir kararlılıkla üstlenerek varlığını geçekleştirir. Ölümlü varlık olması ve varlığını idrak etmesinin içerisinde ölüm korkusunun bulunması, varoluşuna katılan bir gerçeklik olarak, onun bu dünyada kendisini zamansal olarak idrak etmesini sağlamaktadır. İnsan ölüme yaklaştıkça zamansallık ufkunu daha çok anlamakta/idrak etmektedir.

Ölüme yönelik ve ölüme fırlatılmış varlık olarak Dasein, aynı zamanda ölümden sürekli bir kaçış içerisinedir. Bizatihi kendi $D a$ sein'imizin zaten hep ölmekte olduğu, yani kendi sonuna yönelik olarak var olduğu gerçeğini, ölümü her gün başkasının başına gelen bir hadiseye dönüştürmek suretiyle örterek saklamaktadır. Ölüm hadisesini, olsa olsa kendimizin halen yaşamakta olduğunu biraz daha teminat altına aldığı şeklinde göstermektedir. Oysa o ölümden kaçarken de aslında bizatihi herkesin hep ölüme yönelik varlık olarak belirlediği şeye tanıklık etmiş olmaktadır.

O geleceğe/ileriye fırlatılmış bir varlık olması itibariyle, geleceğine ilişkin tasarımlarıyla ileriye doğru koşarken, tirajik olarak aslında ölümüne doğru koşmaktadır. Ne var ki varoluşsallıkla kendini ileriye doğru aşma isteği, ileriye koşarken ona ölüme koştuğunu unutturmaktadır. ${ }^{13}$

Sonuç olarak sözü geçen bu dört ögenin orta yere getirdiği şey, insanın, dolayısıyla aklının tarihsel bir mahiyet olduğudur. İnsan olarak müfessirin tarihselliği, bir taraftan anlamasının tarihselliğini temellendirirken, diğer taraftan ve aynı zamanda onun tefsir diye ortaya koyduğu eserinin tarihselliğini de temellendirmektedir. Ha-

13 Heidegger, Varlık ve Zaman, 268-270. 
kikatte kendisi mecaz olan dil ile dile gelmiş olanın, tarihsel bir mahiyet olan insanın akliyla mutlak hakikat makamında ele alınmasının muhasebesini zorunlu hale getirir.

\section{B. Metnin Mahiyeti}

Felsefi manada metin kavramı sadece yazılı metinleri ifade etmemekte, bunun yerine bütün anlamlı insan eylemlerini ifade etmektedir. Yazılı metinlerin yanında her türden sözlü metin, sanat eserleri, diğer metinlerle farklılığına rağmen musiki tarzında sesli metinler, hatta varlığın tamamı metin kavramı içerisinde düşünülmektedir.

Sözlü söylemin (metinlerin) muhatapları yalnızca konuşma anındaki kişiler iken, yazılı metnin muhatapları sözlü söylemdeki diyalog durumunun aksine eşit koşullarda olmayan okuyuculardır. Yazılı metinlerin okuyucuları, zamansallık, tarihsellik ve kültürellik bakımından farklılık arz ederek ayrışırlar. Fakat yazılı söylem, sözlü diyalog esnasındaki zamansal kısıtlılığa bağlı kalmadan bilinmeyen okuyuculara hitap ederek evrensellik kazanmaktadır. Yazılı ve sözlü metinler gibi diğer anlamlı insan eylemleri de metin gibi ele alınarak okumaya konu olurlar. ${ }^{14}$ İnsanın her türlü eylemi de konuşma gibi bildiri içeriklidir. İnsan eylemi, bildiri içeriğini muhtevi olmasının yanı sıra sözel eylem gibi belirli kurallara göre ifade edilme tarzına da sahiptir. Eylemin bildiri içeriği yanında ifade tarzı, o eylemin yazıyla saptanmasını mümkün kılan anlam içeriğini oluştururlar. ${ }^{15}$

Söz konusu bu metin türlerinin en ayırt edici vasıfları, bu-dünyada-varlık olan Dasein'ın anlamlı eylemleri olmaları itibariyle tarihsel bir mahiyet olmalarıdır. Yazılı ve sözlü metinler ise, diğer tüm metinlerden farklı olarak dilsel-tarihsel metinlerdir. Bu tür metinlerin dilselliği onları diğer metinlerden farklı kılar. Kendileri bir dil hadisesi olan bu metinlerle ilişki de genel anlamda varlıkla kurulan ilişki gibi varoluşsal olarak dil üzerinden kurulmaktadır.

\section{Anlama/Yorumlama}

Heidegger'e göre anlama, varoluşsal bir olaydır ve geleceğe atılmışlığın varoluşsal yapısıdır. Bu yapı, Dasein'in anlamlı bir operasyonu olan anlama için temeldir. İnsan bilimlerindeki gündelik anlamanın

\footnotetext{
14 Paul, Ricoeur, Yorumların Çatışması Hermenoytik Üzerine Denemeler, çev. Hüsamettin Aslan (İstanbul: Paradigma Yayınları, 1990), 1: 27-30.

15 Yasin Aktay, vd. Önce Söz Vardı (Ankara: Vadi Yayınları, 2020), 121.
} 
da temelinde bu yapı yatmaktadır. Gadamer'e göre Heidegger'in anlamayı varoluşsal bir hadise olarak görmesi, onun hermenötiğin en temel ögesini yakaladığını göstermektedir. ${ }^{16}$

Ona göre insan varoluşunun kendini dışa vurma tarzının temeli anlamadır. Varoluşsal olarak bu dünyada anlama, insanın ontolojik yapısına aittir. Nitekim dünya ile ilişkimiz de bir anlama ilişkisidir. İnsan, sürekli bu dünya-da varlık ve ilişkilerinin toplamından oluşan dünyada varlık olarak anlama hali içindedir. ${ }^{17}$

Mahiyeti bakımından anlama, kişinin anlamaya çalıştığı bir metni kendisi için anlamlı hale getirmesidir. Yoksa anlama, adeta tanrısal bir vizyonla onu bütün boyutlarıyla idrak etmesi, künhüne vakıf olması değildir. Bu yüzden Gadamer, "biz daima eksik anlarız" derken, hermenötiğin, geleneksel olarak kendisini bir sanat öğretisi olarak anladı̆̆ını söylemektedir. ${ }^{18}$

Varoluşsalcı hermenötik bakışa göre anlama, temel karakteri itibariyle diyalojiktir. Anlamanın diyalojik karakteri, onun bir konu üzerinde uzlaşmaya varma ve dolayısıyla anlama hadisesinin, bir katılım hadisesi olduğunu ortaya koymaktadır. Nitekim Gadamer'e göre hakikatte anlama, mevcut nesneyle değil, onun etki tarihiyle kurulan özel ilişkidir. Bu ise, onun anlama ile kastettiği şeyin, bir metnin yazarı ile aynı görüşün paylaşılması yerine, aynı zeminin, yani konunun paylaşılması anlamına gelmektedir. Çünkü bir başkasının bakış açısını kavramak için, onun dayandığ1 temeli kavramak gerekir. İşte bu yüzden de bir metni anlarken yazarının niyetini anlama, yazarın dayandığı temeli anlamaya nazaran ikinci derecede kalır. ${ }^{19}$

Gadamer'in anlama hadisesini konu üzerinde temellendirmesi, hakikatin bakış açısına indirgendiği manasına gelmiyor. Çünkü burada gerçek olan, bakış açısının konuya dayandırılarak konunun esas alınmış olmasıdır. Gadamer, burada anlamayı yazarın niyetinin üzerinde temellendiren Hirsch gibi niyetselcileri eleştirerek, bu temellendirmenin konuyu, dolayısıyla da hakikati bakış açısına in-

16 Gadamer, Tarih Bilinci Sorunu, 97.

17 Osman, Bilen, Çă̆daş Yorumbilim Kuramları (Ankara: Kitabiyat Yayınları, 2002), 103.

18 Gadamer, Hakikat ve Yöntem, 2: 3.

19 Burhanettin Tatar, Felsefi Hermenötik ve Yazarın Niyeti (Ankara: Vadi Yayınları, 1999), 156. 
dirgediğini savunmaktadır. Ona göre birini bilmek için onun ufkunu keşfetmeye kalkışarak sorunu çözeceğimizi farz edersek, yapmak istediğimiz şeyi gerçekleştirmekte başarısız oluruz. Çünkü bu durumda nesne üzerinde uzlaşmaya varmamış oluruz. ${ }^{20}$

Gadamer hermenötiğinde anlama, öncelikle konunun tecrübe edilmesi olarak yer alır. Buna göre bir metnin anlamı, herhangi bir tarihsel bireyin bilincini aşan hakikat iddiasında bulunduğu için, "kendisini tecrübe eden şahsı değiştiren bir tecrübe" haline gelir. Böylece metin, kendisinden başka bir noktaya işaret ettiğinde ve yazarın hakkında konuştuğu konuyu görmemizi sağladığında varlık kazanır. ${ }^{21}$

\section{1. Özne-Nesne Düalizmi}

Varoluşsallık temelinde hayat bulan hermenötiği diğer anlama teorilerinden ayıran en önemli husus, bu hermenötiğin özne-nesne ontolojisine ilişkin yaklaşımıdır. Hermenötik, özne ve nesne kavramlarını tartışmaya açarak diğer bütün anlama teorilerinin üzerine oturduğu temeli sorunsallaştırır. Bu teorilerin açık ya da örtük olsun hiçbir şekilde yakasını özne-nesne düalizminden kurtaramamış oldukları söylenebilir. Mesela Gadamer, "Dilthey'ın Tarihselliğin Güçlüklerine Dolanışı" başlıklı makalasinde Dilthey'ın, aydınlanmanın özne-nesne eleştirisi üzerinde şekillenen sisteminin dahi, yakasını bu düalizmden kurtarmadığını ikna edici şekilde ortaya koymaktadır. ${ }^{22}$

Özne-nesne ontolojisine taraftar olanlar, anlamada nesnelliği savunurlarken aslında bir paradoksun içine düştüklerini fark edemiyorlar. Burhanettin Tatar'ın Gadamer'e dayanarak söylediği gibi, onlar nesnelliği savunurlarken aslında öznelliğe düşmekte ve öznelliği savunmuş olmaktadırlar. İlk olarak bu, anlamın varlığını onu oluşturanın zihne indirgemelerinden, ikinci olarak ta özne-nesne üzerinde temellenen yöntem aracılığıyla anlamı nesnel olarak elde edeceklerini düşünmelerinden kaynaklanmaktadır. Çünkü onlara göre, yazarın niyetine yönelerek yorumcu, anlamı kavranabilir bir form içerisinde mevcut ana getirebilir. ${ }^{23}$

\footnotetext{
20 Tatar, Felsefi Hermenötik ve Yazarm Niyeti, 25.

21 Tatar, Felsefi Hermenötik ve Yazarın Niyeti, 48.

22 Gadamer, "Dilthey'ın Tarihselliğin Güçlüklerine Dolanışı”, Metinlerle Hermeneutik Dersleri, Der. Doğan Özlem (İzmir: Prospero Yayınları, 1994).

23 Tatar, Felsefi Hermenötik ve Yazarm Niyeti, 31.
} 
Şayet böyleyse, o halde Tatar'ın sorduğu şu soruların cevaplanması gerekir: "Eğer anlam zaten nesnel, yani tabiatı itibariyle paylaşlabilir değilse, yorumcu onu nasıl kavrayabilir ve şayet o nesnel ve paylaşılabilir ise niçin yorumcu yazarın öznelliğine gitmelidir? Yazarın öznelliği anlamın öznelliği için bir hareket noktası olarak kabul edildiğinde, öznelcilik ve nesnelcilik kaynaşmış olmuyor mu?" 24

Doğrusu, özne ve nesnenin kendilerine ait ontolojik alanlara sahip oldukları ve kendi özdeşlikleri içerisinde bulundukları varsayımı, çözülemeyecek bir ikilemi ortaya çıkarmaktadır. Çünkü, şayet yorumcu özne ile nesne arasında bir mesafenin bulunduğunu var sayıyorsa, bu durumda nesneyi öznenin dönüştürücü etkisinden koruyabilmek için bu mesafeyi korumak zorundadır. Ne var ki bu mesafeyi koruduğu sürece de nesneye, onu kendi tabiatı içinde yeterince anlayacak kadar aşina olamayacak ve bu tutumu, onun nesnenin hakikatini kavramasını engelleyecektir. ${ }^{25}$

Tefsirde, nesnelci eğilimin kendisini daha çok dirayet tefsirinde gösterdiği söylenebilir. Rivayet tefsiri nüzûl ortamının tarihselliğine aşina olmaya olabildiğince imkanlar sunarken, dirayet tefsirinde, farklı zamanlardaki yorumcuların tarihselliği her yeni tefsir etkinliği ile bu aşina olabilme imkanının önüne tarihsel bariyerler koymaktadır. Diğer taraftan her tefsir etkinliği tarihsel kapalılığını bertaraf ederek Kur'an'a yeniden söz söyleme alanı açarken onu yeni bir tarihsel katmanla da kapatmaktadır. Burada Kur'an'ın sözü aynı anda hem açılmakta hem de paradoksal olarak kapalı hale gelmektedir. Tefsirde nesnelciliğin tesiri ne kadar çoğalırsa Kur'an'ın sözü de o nispette kendisine yabancılaşır. Zira nesnelcilikte metnin anlamı, yorumcunun tarihsel anlam dünyasıyla şekillenmiş kanaatlerinin yorum konusu olan metinle dile getirilendir.

\section{Gelenek}

Hermenötik anlama sanatında gelenek, aydınlanmacı felsefelerin aksine, müspet bir anlama kavuşturulmuştur. Buna göre gelenek ne arkamızı döneceğimiz ne de kendisinden kurtulacağımız bir olgudur. Zaten bu, varoluşsal olarak mümkün de değildir. Aksine gelenek, bizi yapılandıran, dolayısıyla bizi biz yapan en temel varoluşsal varlık zeminidir. Öte yandan gelenek, geçmişi bize ulaştıran, geçmiş ile irtibatımızı sağlayan, bu nedenle de geçmişi ve bugünü

24 Tatar, Felsefi Hermenötik ve Yazarm Niyeti, 31.

25 Tatar, Felsefi Hermenötik ve Yazarm Niyeti, 39-40. 
anlamlandıran ve anlamamızı sağlayan şeydir. Bize şeyler hakkında ön-anlamayı ve ön-yargıyı sağlayan da gelenektir.

Zaten bizler daima bir gelenek içerisinde var oluruz. Ne var ki gelenek içerisinde var olmak, bir taraftan ön-anlamamızı temin eden şey iken diğer taraftan, paradoksal olarak metnin bize söyleyeceği şeyin duyulmasını, fark edilmesini engelleyen şeydir. Gadamer' in değindiği gibi, "Bizi gelenek içinde bizimle konuşan şeye sağır hale getiren, gizli önyargıların tiranlığıdır." 26

Hermenötik yaklaşım geleneği felsefi anlamda varoluşsallıkla ilişkilendiriken buna karşılık tefsir faaliyeti, geleneği daha çok değer açısından ele alma eğiliminde olmuştur. Fakat bu yaklaşımda ister müspet ister menfi olarak değerlendirilsin, yorumcu ile kendi geleneği arasındaki varoluşsal ilişki göz ardı edilmektedir. Halbuki her tefsirci kendi geleneği içerisinde şekillenirken yorum öncesi önanlamasını kendi geleneği belirlemektedir.

\section{3. Önyarg1}

Doğası itibariyle anlama, daha baştan geleneğin bize kazandırdığı ön-anlama/ön-yarg1 zemininde başlar. Fakat "bir şeyi anlamaya çalışan kişinin kendisinin, daha baştan kendi arızî ön-anlamlarına teslim olmaması gerekir; inatla kulak asmazsa metnin gerçek anlamını işitemez ve böylece metnin asıl anlamını bertaraf etmiş olur. Metni anlamaya çalışan kişi, karşısında durduğu metnin kendisine bir şey söylemesine hazır olmalıdır. Hermenötik eğitimli/donanımlı bilinç, daha baştan metnin farklılığına duyarlı olmak zorundadır. Fakat bu duyarlılık türü ne içerik konusunda "nötrlük" gerektirir ne de kişinin kendisini ortadan kaldırmasını gerektirir; tersine bu duyarlılık türü kişinin kendi ön-anlamlarının ve önyargılarının ön-temellere dönüştürülmesini ve temellükünü gerektirir. Önemli olan şey kişinin kendi önyargılarının farkında olmasıdır. Öyle ki, metin kendisini çıplak ötekiliği ile sunabilsin ve dolayısıyla kendisine özgü objektif hakikati, kişinin kendi ön-anlamları karşısında açıkça sergileyebilsin." 27

Her anlamanın kaçınılmaz biçimde bir önyargıyı içerdiğinin kabulü, hermenötik problemi ön plana çıkarır. Hermenötik literatürde önyargı kavramı, etimolojisine de uygun olarak yanlış yargı anlamına gelmez. Hermenötik'te bu kavram, hem pozitif hem de

\footnotetext{
26 Gadamer, Hakikat ve Yöntem, 2: 10.

27 Gadamer, Hakikat ve Yöntem, 2: 9.
} 
negatif değere sahip olabilecek bir düşünce unsuru olarak yer alır. Her ne kadar "insan zihni önyargısız işlemeyecek kadar zayıfsa da, en azından doğru önyargılarla eğitilecek kadar şanslıdır." 28

\section{Varlığın Kendisini İfşası}

Kur'an tefsir geleneğinde anlama, daha çok metnin tarihsel ve dilsel boyutu hakkında yeterli malumat sahibi olma dışında anlama konusunda herhangi bir sorunu olmayan öznenin metin analizi ile ulaştığı hasıla olarak öne çıkmaktadır. Bu bakımdan geleneksel tefsir ameliyesine özne-nesne ontolojisinin egemen olduğu söylenebilir. Araştırılmaya soruşturulmaye konu olan neredeyse sadece metindir. Bu ameliyede metin mutlak nesne olarak yer alırken, müfessir özne konumunu her daim muhafaza etmektedir. Müfessirin tarihselliğinin metnin anlamını manipüle edebileceğinin hesabı pek gözükmez.

Buna karşllık hermenötik anlama sanatında anlama, bir özne olarak insanın nesneleri dolaysız kavraması, onların üzerinde gerçekleştirdiği operasyonlar ile değil, aksine varlığın kendini ifşası ile gerçekleşir. Özellikle Gadamer hermenötiği, Heidegger'in hakikati ifşa, ya da konunun (sache) parlaması olarak gören felsefesinden yola çıkmaktadır. Buna göre herhangi bir hakikat iddiasında olarak ortaya çıkan şey, bizzat nesnenin kendini ifşası, yani kendini açması olduğu için, her daim hakikat, bir ifşa olarak anlaşılmalıdır. Bu ifşa ise, her şeyden önce nesnelerin ifşasının arka planı olarak dünyanın ifşasına işaret etmektedir. Heidegger hermenötiğine dayanan bu hakikat-ifşa ilişkisi bakımından nesneler, hem zaten ifşa olmuş hem de gizli durumda olurlar. Tecrübeler dünyasının içerisinde kendine özgü var oluş tarzı ile Dasein olarak insan, hem hakikat, yani ifşa hali içinde, hem de hakikat dışı, yani gizli varlık olarak henüz kendini ifşa etmemiş bir halde bulunur. Zaten burada hakikat ön-kavramı, hem nesnelerin ifşasının dünyanın ifşası üzerinde gerçekleştiğine, hem de ifşa olmanın Dasein'in temel bir niteliği olmasına işaret etmektedir. Hakikat ise daima sınırlı bir ifşa olduğundan, bir şeye ışık tutmak, yani onu açmak, aynı zamanda onun başka bir yüzünü karanlıkta bırakmak olur. ${ }^{29}$ Hakikat-ifşa ontolojisi ile ilgili olarak Burhanettin Tatar şöyle demektedir:

28 Gadamer, Hakikat ve Yöntem, 2: 14.

29 Bk. Tatar, Felsefi Hermenötik ve Yazarın Niyeti, 97-99. 
"Şayet her hakikat fani, yani sınırlı ve ifşa bir süreç ise, bu durumda ifşanın orijinalliği ifşa edilen varlığın farklı bir veçhesine ve biricikliğine işaret eder. Bu demektir ki, hiçbir keşif ya da ifşa, başka bir keşfe indirgenemeyeceği ve diğer bir hakikatle yer değiştiremeyeceği için, ifşa olarak her hakikat kendine özgü bir niteliğe, alana ve sinıra aittir." 30

"Hakikat" kavramına felsefi bakımdan bu şekildeki bakış tarzı, hakikati, yani anlamı, metnin lafzında, yazarın niyetinde ya da önyargilarda donduranların aksine olarak, yorumu dinamik bir pozisyonda tutma kabiliyetine sahiptir. Bu ise yorumun, hakikatin tarihsel öznel tezahürleri olduğunu ve hakikatin tarihsel sürekliliğe sahip olduğunu göstermektedir. Çünkü her yorum nesnenin/metnin anlamını farklı bir açıdan aydınlatır.

Yorum, tabiatı itibariyle hiçbir zaman sıfır noktasından başlamaz. O, tarihsel olarak etki altında olan bir bağlamın hakikatinden hareket eder. Bu ise, "mevcut bağlam ya da ufkun kendi ışı̆̆ını tarihten aldığı anlamına gelir. Böylece mevcut an, kendisini geçmişten ayırarak değil, kaynağı olan tarihsel sürecin yeni bir boyutunu tezahür ettirerek farklılık arz eder." 31

Açık olan şu ki, metin ve yorum ancak, daima yeni bir yöne işaret etmek suretiyle var olabilirler. Geçmiş bir metni mevcut ana getiren ve bir yorumu aynı metnin diğer yorumlarından ayıran, dolayısıyla da canlı kılan şey budur. Aksi durumda, hem metin önceki yorumlarından ayırt edilemez duruma gelir, hem de yapilacak yorumlar, zaten söylenmiş olanın tekrarından ibaret olacağı için bu yorumlar farklı varlıklar olarak tezahür edemezler. Bu nedenle, paradoksal gözükse de metinler varlıklarını ancak farklı yorumlarla tezahür ettirebilirler. Çünkü, eğer yorumlar arasında farklılık olmayacaksa, bu durum, metnin varlığının değişen şartların gerçekliğinden koparak kendi içinde durağanlaşacağı manasına gelir. Bu bakımdan bir metne yorum açısından değişmez bir anlam olarak yaklaşmak, bu metnin artık hayattan, canlılıktan yoksun olması manasına gelir. Bu da şimdi ile geçmiş arasında esaslı bir kopukluğun bulunduğunu kabul etmek olacağı için, metnin tarihsel sürekliliğinin bulunmadığını kabul etmekle eş değer olacaktır. Yani söz konusu metin, değişen şartlar ve farklı tarihsel durumlara kayıtsız kalmak

30 Tatar, Felsefi Hermenötik ve Yazarm Niyeti, 101.

31 Tatar, Felsefi Hermenötik ve Yazarm Niyeti, 115. 
durumunda kalacağı için yeni bir şey söyleme, başka bir ifade ile söz söyleme gücünü kaybetmiş olacaktır. ${ }^{32}$ Dolayısıyla yorumla hayat bulan hakikat, sınırlı bir ifşa hali ve hakikatin tecrübe edilmesi olarak her yorum, hakikati sadece bir yönüyle ifade ederek onu sürekli ve dinamik kılmaktadır. Bu bakımdan hakikatin/yorumun nesnelliği iddiası, epistemolojilerin bir iyimserliği olmanın ötesine geçmez. Zira bu, hakikatin süreksizliği, donmuşluğu manasına gelir.

Netice olarak, varoluşsal hermenötikte hakikatin anlaşılması sorunu, yani yorum sorunu, bir epistemoloji sorunu ya da yazarın niyetinin bilinmesi sorunu değil, bir konu üzerinde ufukların kaynaşması sorunu olarak görülmektedir. Dolayısıyla hakikat, metinle karşılıklı konuşma sürecinde ortaya çıkan şeye işaret eder. Hakikatin diyalojik yönüne büyük önem atfeden Gadamer, bu yüzden $H a$ kikat ve Yöntem isimli meşhur kitabında bu konuya geniş bir yer ayırarak Sokratik-Platonik diyalogların önemi üzerinde durur, onlar üzerinden hakikatin diyalojik karakterini analiz etmeye çalışır. Bu bağlamda o şöyle demektedir:

Anlamak isteyen kişi söylenen şeyin arkasında ne yattığını sormalıdır. O bunu bir soruya cevap olarak anlamalıdır. Söylenen şeyin arkasına gidersek, kaçınılmaz şekilde söylenen şeyin ötesine sorular yöneltmiş oluruz. Metnin anlamını, yalnızca sorunun ufkuna -aslında başka cevapları da içeren ufuktur - ulaşırsak anlayabiliriz. Kaldı ki, bir cümlenin anlamı, cevabı olduğu soruya bağlıdır, fakat bu, anlamın zorunlu olarak onda söylenen şeyi aştı̆̆ına imada bulunur." 33

Gadamer'in, evrensel hermenötiğin temel sorunları bağlaminda yapmış olduğu analizler, daha önce işaret edildiği üzere, insanın, dilin, dünyanın ve aynı zamanda anlama nesnesinin tarihselliği üzerinde temellenmektedir. Dolayısıyla Kur'an'ın çağdaş tefsiri, bu temelleri dikkate alarak her yeni durumda, her yeni tarihsellikte sözünü söyleyebilmelidir. Aksi takdirde daha önce değinildiği gibi, Kur'an'ın birbirinin tekrarı durumundaki yorumları, aynı şeyi söyleyerek metni yorumla özdeş hale getirirken aynı zamanda Kur'an metnini de durağanlığa sürükleyerek onu canlı metin olmaktan çıkarır. Bu da Kur'an metninin tarihsel süreksizliği manasına gelir.

32 Tatar, Felsefi Hermenötik ve Yazarın Niyeti, 116.

33 Gadamer, Hakikat ve Yöntem, 2: 152. 


\section{Sonuç}

Görüldüğü gibi hermenötik, geleneksel tefsir/yorum modellerinin aksine metinleri öne çıkarmak yerine yorumcuyu öne çıkararak yorumun mahiyetini tartışmaktadır. Geleneksel yorum modellerindeki mutlakçı yaklaşım yerine insan varoluşsallığına bağlı olarak görece sübjektif bir yaklaşımı öne çıkarmaktadır.

Buna göre yorum, her daim eksik olan, sübjektif, tarihsel ve doğruluğu görece olan bir hasıladır. Buradan da şu sonuç çıkar: Hiçbir yorum, mutlak doğru, mutlak hakikat olarak kendisini dayatma makamında olamaz. Yorumun sübjektif karakteri, hiçbir alanda Gadamer'in ifadesiyle tiranlığa yol vermez. Diğer taraftan bu bakış açısı gerçek bir bilince dönüştüğünde, insan ilişkilerinde, düşünsel karşılaşmalarda verimli bir hoşgörü zemini inşa edilmiş olur. Yanı sıra hem anlama hadisesinde sonuçlara ulaşmada hem de hayata ilişkin konularda çeşitli despotizmler üretmenin zeminini de yok eder. Bu bakımdan, anlamanın hayat süreci içerisinde daima kendini aşan, kendini yenileyen bir hadise olduğunu, dolayısıyla anlamaya konu olan metni yeniden ve yeniden anlama nesnesi diye tasavvur ederek onunla ilişkiyi daim kılmak olduğunu, bilince dönüştürmek gerekmektedir.

İşte bu mülahazalar, tefsiri metin ve metin analiziyle sınırlandırarak müfessirin varoluşsal/tarihsel mahiyetini araştırma dışı bırakan bir yorum anlayışının, ne kadar sorunlu olacağını göstermektedir.

\section{Kaynakça}

Aktay, Yasin vd. Önce Söz Vardı. Ankara: Vadi Yayınları, 2020.

Bilen, Osman. Çă̆daş Yorumbilim Kuramları. Ankara: Kitabiyat Yayınları, 2002.

Gadamer, Hans-Georg. “Tarih Bilinci Sorunu”, Toplum bilimlerinde Yorumcu Yaklaşım. çev. Taha Parla. İstanbul: Hürriyet Vakfı Yayınları, 1990. . "Dilthey'ın Tarihselliğin Güçlüklerine Dolanışı". Metinlerle Hermeneutik Dersleri. Der. Doğan Özlem. İzmir: Prospero Yayınevi, 1994. . Hakikat ve Yöntem, çev. Hüsamettin Arslan, İsmail Yavuzcan, İstanbul: Paradigma Yayınları, 2008.

Kotan, Şevket. Kur'an ve Tarihselcilik. İstanbul: Beyan Yayınları, 2001.

Martin, Heidegger. Varlık ve Zaman. çev. Kaan H. Ökten. İstanbul: Agora Kitaplığı, 2008.

Özlem, Doğan. Tarih Felsefesi. İstanbul: Ara Yayınları, 1992.

Palmer, Richarde E. Hermenötik. çev. İbrahim Görener, İstanbul: Anka Yayınları, 2002. 
Şerket KOTAN

Ricoeur, Paul. Yorumların Çatışması Hermenoytik Üzerine Denemeler. çev. Hüsamettin Aslan. İstanbul: Paradigma Yayınları, 1990.

Tatar, Burhanettin. Felsefi Hermenötik ve Yazarm Niyeti. Ankara: Vadi Yayınları, 1999. 